\title{
Combination of an experiment of Ampère with an experiment of Faraday
}

\section{J. J. Taudin Chabot}

To cite this article: J. J. Taudin Chabot (1899) Combination of an experiment of Ampère with an experiment of Faraday, Philosophical Magazine Series 5, 47:286, 331-331, DOI: $10.1080 / 14786449908621268$

To link to this article: http://dx.doi.org/10.1080/14786449908621268

册 Published online: 08 May 2009.

Submit your article to this journal $\pi$

Џ Article views: 2

Q View related articles 5 


\section{COMBINATION OF AN EXPERIMENT OF AMPERE WITH AN}

EXPERIMEST OF FARADAY. BY J. J. TAUDIN CHABOT.

It was shown by Ampère * how a magnet can be made to rotate about its axis under the influence of $a$ steady current, and Faraday $\dagger$ showed how the rotation of a magnet about its axis can give rise to a steady current + .

By combining these two experiments we obtain a case of induction by steady currents : a steady primary current in the

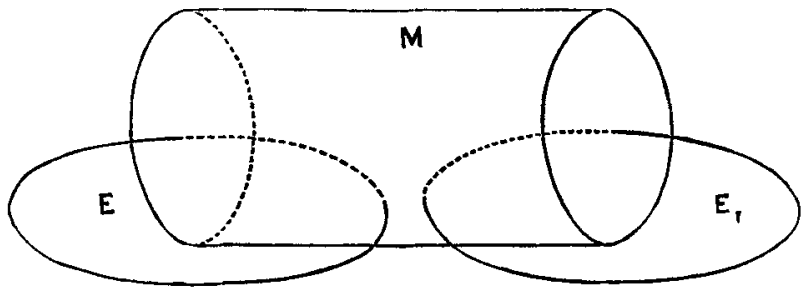

circuit $\mathbf{E}$ or $\mathbf{E}_{1}$ gives rise to a steady secondary current in the circuit $\mathrm{E}_{1}$ or $\mathrm{E}$, a rotating magnet $\mathrm{M}$ forming the connecting link.

In order to show the effect, a brake is applied to the magnet $M$, a battery is inserted into the circuit $\mathrm{E}$ or $\mathrm{E}_{1}$ and a galvanometer into the other circuit $\mathbf{E}_{1}$ or $\mathbf{E}$. On closing the circuit we observe that the suspended system of the galvanometer remains at zero; but, on removing the brake from the magnet, this begins to rotate and the galvanometer shows a deflection which increases continuously until the magnet turns quite freely. A brake is desirable which admits of a graduated application.

It appears to me that this experiment is worthy of notice in consideration of its illustrative character $\S$.

Degerloch (Württemberg),

December 12th, 1898.

\section{EXPERIMENTS WITH THE BRUSH DISCHARGE.}

To the Editors of the Philosophical Magazine.

GeNTLIMEN,

I have read with considerable interest the paper by Dr. Cook on the "Brush Discharge" in the January number of your Magazine. May I be allowed to call attention to some experiments made by Lord Blythswood about two years ngo, which are of a very

* Recueil d'Observations, p. 177 (1821). Lettre à M. van Beck.

† 'Experimental Researches,' series ii., $\$ \$ 217-230$ (1832); see also series xxviii. (1851).

$\ddagger$ This phenomenon is generally known by the name of "unipolar" induction; "autopolar" induction (induction autopolaire, Gleichpolinduction), it seems to me, would be better; and therefore 1 propose this term. Then, in contradistinction, "heteropolar" induction (induction héteropolaire, Wechselpolinduction) can be used for signifying induction by both the poles alternately (dynamo \&c.).

\$ See Phil. Mag. vol. xlvi. p. 428 (Oct. 1898), and p. 571 (Dec. 1898). 